\title{
Mechanism of Active DNA Demethylation: Recent Progress in Epigenetics
}

\section{Atanu Maiti*}

Department of Biochemistry and Molecular Biology, University of Maryland School of Medicine, Baltimore, MD 21201, USA

In early 1940s, British Biologist Conrad Waddington coined the term "Epigenetics" blending the terms Epigenesis and Genetics, to interpret how genes interact with their surroundings to produce a phenotype. Since then, accumulative research has improved our understanding in this field and also expanded the meaning of the term epigenetics. Epigenitics broadly describes the study of stable heritable changes in gene function that occur without any alteration of the DNA sequences. Epigenetic processes are essential for development and cellular differentiation, and are also responsible for aging and development of several diseases, including cancer. Evidence indicates that both cellular (endogenous) and environmental factors influence epigenetic processes [1-3]. These processes include DNA methylation, histone modifications, and micro RNAs, and they can help to explain how cells with identical DNA can differentiate into different cell types.

Among the various epigenetic processes, DNA methylation is important, and plays a key role in gene expression, genomic imprinting, $\mathrm{X}$-chromosome inactivation, genomic instability and embryonic development. While proper methylation is important for development, aberrant methylation is implicated in tumorigenesis and cancer. DNA methylation is an enzymatic process that replaces hydrogen with a methyl group at the $5^{\text {th }}$ carbon position of cytosine. In mammals, most cytosine methylation occurs at a particular DNA sequence, a 5'CpG-3' dinucleotide. These CpG sites are often clustered together, and these clusters are referred to as CpG islands. This DNA modification is catalyzed by DNA methyl transferase (DNMTs). Previously, it was thought that DNA methylation is a static process and that DNMTs are exclusively responsible for maintenance of methylation status in DNA. With time, numerous findings pointed out that modulation of methylation status is important for proper development and suggested that DNA methylation should be reversible like most other biological processes such as phosphorylation, acetylation, etc.

Though mechanism of cytosine methylation via DNMTs is well established, the mechanism of demethylation has remained obscure. It was proposed that DNA demethylation can be passive, active, or a combination of both mechanisms. Passive DNA demethylation can occur by inhibition or lack of DNA methyltransferase activity during cycles of DNA replication. In contrast, active DNA demethylation is mediated by specific enzymes and can occur in the absence of DNA replication. Three different mechanisms have been proposed for active DNA demethylation. First, it was proposed that the methyl group can be directly removed from 5-MethylCytosine $(\mathrm{mC})$ by specific enzyme. Second, the $\mathrm{mC}$ base (or a modified version of $\mathrm{mC}$ ) can be excised by a DNA glycosylase, and then the resulting basic nucleotide is replaced with deoxycytidine via the base excision repair (BER) pathway. Whereas the third mechanism proposes a nucleotide excision repair pathway to remove a methylated cytosine and it is replaced by an unmethylated cytosine $[4,5]$. No enzyme has been detected yet in support of above. There are no direct evidences which support the first and third mechanism. However, increasing evidences support the second mechanism of active DNA demethylation via the excision of methyl cytosine (in plants) or modified methyl cytosine (in animals) by specific DNA glycosylase through the BER pathway [5]. In animals, two mismatch repair DNA glycosylases, Thymine DNA Glycosylase
(TDG) and Methyl CpG-binding Domain Protein 4 (MBD4) were thought to be involved in active DNA demethylation, involving a two step processes. First, active deamination of $\mathrm{mC}$ by an AID or APOBEC enzyme generates a GT mispair, then TDG or MBD4 excises T from the mispair, and subsequent BER restores the GC base pair. However, clear evidence was lacking for such a mechanism. A number of recent studies have improved our knowledge on active DNA demethylation [6].

The discovery of 5-hydroxymethylcytosine (hmC), referred to as the $6^{\text {th }}$ base in DNA, has made a significant contribution in the field of epigenetics. While hmC was detected in bacteriophage DNA in 1952 and animal DNA in 1972, the findings drew little attention until 2009, when it was reported that (Tet1) Ten-Eleven-Translocation 1 mediates the conversion of $\mathrm{mC}$ to $\mathrm{hmC}[7,8]$. It was subsequently reported that the other mammalian Tet enzymes (Tet2, Tet3) also convert $\mathrm{mC}$ to $\mathrm{hmC}$ [9], and that $\mathrm{hmC}$ has a probable role in transcriptional regulation [10]. More recently, it was reported that Tet enzymes can oxidize hmC to 5-formylcytosine (fC) and 5-carboxycytosine ( $\mathrm{caC}$ ), and that these bases are present in genomic DNA. It was suggested that caC could be converted to $\mathrm{C}$ by a decarboxylase [11], but such an enzyme has not yet been identified.

In 2011, it was reported that TDG is essential for embryonic development and for active DNA demethylation, involving TDG excision of either deaminated or hydroxylated $\mathrm{mC}$ followed by BER $[12,13]$. Subsequently, He et al. [14] reported that TDG can excise caC, the final Tet-mediated oxidation product of $\mathrm{mC}$, and that depletion of TDG leads to accumulation of $\mathrm{caC}$ in DNA, while caC was not detected in TDG-proficient cells. At the same time, Maiti and Drohat showed that TDG can efficiently remove both $\mathrm{fC}$ and $\mathrm{caC}$ from DNA, and that the rate of $\mathrm{fC}$ excision is much (5-fold) faster than $\mathrm{caC}$ [15]. Maiti and Drohat noted that TDG excision of fC could potentially account for the observations by Raiber EA et al. that depletion of TDG causes an elevation of $\mathrm{caC}$ (and that $\mathrm{caC}$ is not detected in TDG proficient cells), because $\mathrm{fC}$ is a precursor for $\mathrm{caC}$, and Tet-mediated conversion of $\mathrm{fC}$ to $\mathrm{caC}$ is relatively inefficient. A very recent finding of genome wide distribution of $\mathrm{fC}$ in ES cells, its association with transcription and dependence on TDG, support the TDG-mediated fC excision pathway [16]. However, more research is needed to establish the actual pathway. Another possibility was the removal of Tet-mediated oxidation products of $\mathrm{mC}$ by MBD4, another mismatch repair DNA glycosylase thought to be associated with active DNA demethylation. However, the lack of $\mathrm{mC}, \mathrm{hmC}, \mathrm{fC}$ or caC excision activity of MBD4 rules out this possibility

${ }^{*}$ Corresponding author: Atanu Maiti, Department of Biochemistry and Molecula Biology, University of Maryland School of Medicine, Baltimore, MD 21201, USA Tel: (410) 227-9647; E-mail: amait28@gmail.com, amait001@umaryland.edu

Received October 25, 2012; Accepted October 26, 2012; Published October 31,2012

Citation: Maiti A (2012) Mechanism of Active DNA Demethylation: Recent Progress in Epigenetics. J Biomol Res Ther 1:e106. doi:10.4172/2167-7956.1000e106

Copyright: (c) 2012 Maiti A. This is an open-access article distributed under the terms of the Creative Commons Attribution License, which permits unrestricted use, distribution, and reproduction in any medium, provided the original author and source are credited. 
Citation: Maiti A (2012) Mechanism of Active DNA Demethylation: Recent Progress in Epigenetics. J Biomol Res Ther 1:e106. doi:10.4172/2167$7956.1000 \mathrm{e} 106$

$[14,17]$. These results are perhaps consistent with previous findings that, unlike TDG, MBD4 is not essential for embryonic development [18].

An alternate mechanism of active DNA demethylation was also proposed, whereby AID/APOBEC enzymes deaminate $\mathrm{mC}$ or $\mathrm{hmC}$ to thymine or hmU, respectively, followed by removal of $\mathrm{T}$ by TDG or MBD4, and removal of hmU by TDG, SMUG1, or MBD4 $[6,15]$. Recently, it has been shown that AID/APOBEC enzymatic activity is inversely proportional to the size of the substituent at the $\mathrm{C} 5$ position of cytosine. Thus, AID/APOBEC enzymes have substantially reduced activity on $\mathrm{mC}$ relative to cytosine, and $\mathrm{hmC}$ is not a substrate of AID/APOBEC enzymes [19,20]. These observations raise questions about whether the AID/APOBEC-mediated deamination pathway can account for active DNA demethylation. Together, these recent and important findings have elevated TDG and the Tet enzymes to the forefront of epigenetics, and suggest that they may be attractive targets for future therapeutics.

\section{References}

1. Jaenisch R, Bird A (2003) Epigenetic regulation of gene expression: How the genome integrates intrinsic and environmental signals. Nat Genet 33: 245-254.

2. Ling C, Groop L (2009) Epigenetics: A molecular link between environmenta factors and type 2 diabetes. Diabetes 58: 2718-2725.

3. Li Y, Daniel M, Tollefsbol TO (2011) Epigenetic regulation of caloric restriction in aging. BMC Med 9: 98

4. Jost JP (1993) Nuclear extracts of chicken embryos promote an active demethylation of DNA by excision repair of 5-methyldeoxycytidine. Proc Nat Acad Sci U S A 90: 4684-4688.

5. Kapoor A, Agius F, Zhu JK (2005) Preventing transcriptional gene silencing by active DNA demethylation. FEBS Lett 579: 5889-98.

6. Nabel CS, Manning SA, Kohli RM (2012) The curious chemical biology of cytosine: deamination, methylation, and oxidation as modulators of genomic potential. ACS Chem Biol 7: 20-30.

7. Kriaucionis S, Heintz N (2009) The nuclear DNA base 5-hydroxymethylcytosine is present in Purkinje neurons and the brain. Science 324: 929-930.

8. Tahiliani M, Koh KP, Shen Y, Pastor WA, Bandukwala H, et al. (2009) Conversion of 5-methylcytosine to 5-hydroxymethylcytosine in mammalian DNA by MLL partner TET1. Science 324: 930-935.

9. Ito S, D'Alessio AC, Taranova OV, Hong K, Sowers LC, et al. (2010) Role of Tet proteins in $5 \mathrm{mC}$ to $5 \mathrm{hmC}$ conversion, ES-cell self-renewal and inner cell mass specification. Nature 466: 1129-1133.

10. Pastor WA, Pape UJ, Huang Y, Henderson HR, Lister R, et al. (2011) Genomewide mapping of 5-hydroxymethylcytosine in embryonic stem cells. Nature 473 394-397.

11. Ito S, Shen L, Dai Q, Wu SC, Collins LB, et al. (2011) Tet proteins can convert 5-methylcytosine to 5-formylcytosine and 5-carboxylcytosine. Science 333: 1300-1303.

12. Cortázar D, Kunz C, Selfridge J, Lettieri T, Saito Y, et al. (2011) Embryonic letha phenotype reveals a function of TDG in maintaining epigenetic stability. Nature 470: 419-423.

13. Cortellino S, Xu J, Sannai M, Moore R, Caretti E, et al. (2011) Thymine DNA glycosylase is essential for active DNA demethylation by linked deaminationbase excision repair. Cell 146: 67-79.

14. He YF, Li BZ, Li Z, Liu P, Wang Y, et al. (2011) Tet-mediated formation of 5 -carboxylcytosine and its excision by TDG in mammalian DNA. Science 333: 1303-1307.

15. Maiti A, Drohat AC (2011) Thymine DNA glycosylase can rapidly excise 5-formylcytosine and 5-carboxylcytosine: potential implications for active demethylation of CpG sites. J Biol Chem 286: 35334-35338.

16. Raiber EA, Beraldi D, Ficz G, Burgess H, Branco MR, et al. (2012) Genomewide distribution of 5-formylcytosine in ES cells is associated with transcription and depends on thymine DNA glycosylase. Genome Biol 13: R69.

17. Manvilla BA, Maiti A, Begley MC, Toth EA, Drohat AC (2012) Crystal structure of human methyl-binding domain IV glycosylase bound to abasic DNA. J Mo Biol 420: 164-175.

18. Millar CB, Guy J, Sansom OJ, Selfridge J, MacDougall E et al. (2002) Enhanced CpG mutability and tumorigenesis in MBD4-deficient mice. Science 297: 403405.

19. Rangam G, Schmitz KM, Cobb AJ, Petersen-Mahrt SK, et al. (2012) AID Enzymatic Activity Is Inversely Proportional to the Size of Cytosine C5 Orbital Cloud. PLoS One 7: e43279.

20. Nabel CS, Jia H, Ye Y, Shen L, Goldschmidt HL, et al. (2012) AID/APOBEC deaminases disfavor modified cytosines implicated in DNA demethylation. Nat Chem Biol 8: 751-758. 